\begin{tabular}{|c|c|}
\hline & Aleksandra Figurek \\
\hline \multirow[t]{2}{*}{ AUTHORS } & R http://www.researcherid.com/rid/M-8580-2015 \\
\hline & $\begin{array}{l}\text { Larysa Shynkarenko } \\
\text { Oleksandr Kovalenko }\end{array}$ \\
\hline ARTICLE INFO & $\begin{array}{l}\text { Aleksandra Figurek, Anatoliy Goncharuk, Larysa Shynkarenko and Oleksandr } \\
\text { Kovalenko (2019). Measuring the efficiency of higher education: case of Bosnia } \\
\text { and Herzegovina. Problems and Perspectives in Management, 17(2), 177-192. } \\
\text { doi:10.21511/ppm.17(2).2019.13 }\end{array}$ \\
\hline DOI & http://dx.doi.org/10.21511/ppm.17(2).2019.13 \\
\hline RELEASED ON & Wednesday, 15 May 2019 \\
\hline RECEIVED ON & Monday, 25 March 2019 \\
\hline ACCEPTED ON & Monday, 06 May 2019 \\
\hline LICENSE & $\begin{array}{l}(c)) \text { EY } \\
\text { This work is licensed under a Creative Commons Attribution } 4.0 \text { International } \\
\text { License }\end{array}$ \\
\hline JOURNAL & "Problems and Perspectives in Management" \\
\hline ISSN PRINT & $1727-7051$ \\
\hline ISSN ONLINE & $1810-5467$ \\
\hline PUBLISHER & LLC "Consulting Publishing Company "Business Perspectives" \\
\hline FOUNDER & LLC "Consulting Publishing Company "Business Perspectives" \\
\hline
\end{tabular}

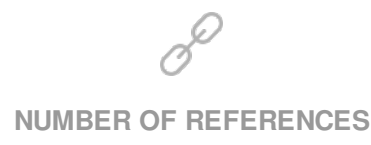

36

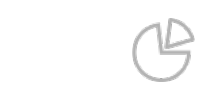

NUMBER OF FIGURES

9

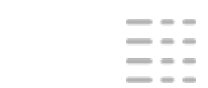

NUMBER OF TABLES

3

(C) The author(s) 2021. This publication is an open access article. 


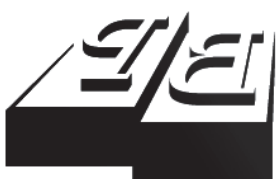

BUSINESS PERSPECTIVES

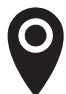

LLC "CPC "Business Perspectives" Hryhorii Skovoroda lane, 10, Sumy, 40022, Ukraine

www.businessperspectives.org

Received on: $25^{\text {th }}$ of March, 2019 Accepted on: $6^{\text {th }}$ of May, 2019

(C) Aleksandra Figurek, Anatoliy Goncharuk, Larysa Shynkarenko, Oleksandr Kovalenko, 2019

Aleksandra Figurek, Ph.D., Assosiate Professor, University of Banja Luka, Bosnia and Herzegovina.

Anatoliy Goncharuk, Ph.D., Dr. habil., Professor, Department of Business Administration and Corporate Security, International Humanitarian University, Ukraine.

Larysa Shynkarenko, Ph.D., Docent, International Humanitarian

University, Ukraine.

Oleksandr Kovalenko, Ph.D., Dr. habil., Professor, Odessa National Polytechnic University, Ukraine.

\section{(c) (1)}

This is an Open Access article, distributed under the terms of the Creative Commons Attribution 4.0 International license, which permits unrestricted re-use, distribution, and reproduction in any medium, provided the original work is properly cited.

Aleksandra Figurek (Bosnia and Herzegovina), Anatoliy Goncharuk (Ukraine),

Larysa Shynkarenko (Ukraine), Oleksandr Kovalenko (Ukraine)

\title{
MEASURING THE EFFICIENCY OF HIGHER EDUCATION: CASE OF BOSNIA AND HERZEGOVINA
}

\begin{abstract}
This paper is devoted to measuring the efficiency of the higher education of Bosnia and Herzegovina. The data envelopment analysis method was applied, considering the number of enrolled students, budget financing, co-financing, self-financing as inputs, and the number of graduated students according to the field of education as the output. Measuring the relative efficiency of main fields of the higher education system of Bosnia and Herzegovina, the authors found that the agriculture is the most efficient field of higher education in this country. However, the engineering, manufacturing technologies and construction field have the lowest efficiency score due to the high consumption of budget expenditures, but the lowest education results. The hypothesis of the growing efficiency of the higher education system of Bosnia and Herzegovina was not confirmed. The downward trend in the total number of publications indicates a twofold deterioration in the scientific efficiency of Bosnia and Herzegovina for the six-year period. Comparison with neighboring countries showed relatively low scientific efficiency of Bosnia and Herzegovina. The conclusion is that currently the higher education system in Bosnia and Herzegovina is relatively inefficient and its efficiency falls down.
\end{abstract}

\section{Keywords}

\section{JEL Classification I21, I23, C14}

\section{INTRODUCTION}

The development of education is a symbol of national strength and the level of economic and social development. The objective of higher education consists in establishing adequate experts who are capable to transfer knowledge to the students, and also to increase the general theoretical and professional levels. In fact, investment in the education system is an investment in the future of mankind. Hence, the improving efficiency of higher education is a highly topical problem for society.

Education differs from other sectors in that the idea of mandating is less defined and accepted and the means to achieve it is more fragmented due to the autonomous nature of institutions (A report by the Universities UK Efficiency and Modernisation Task, Group Universities UK, 2011).

Undoubtedly, the development of excellent subject knowledge is important, but is not enough for an innovative society. In addition to raising academic achievement across all levels of education, innovations policies need to pay more attention to the skills young people acquire (Education Innovation and Research OECD, 2015).

Higher education helps countries build globally competitive economies by creating, applying, and spreading new ideas and technologies, as well 
as developing a skilled, productive, and flexible labor force (Salmi, 2009). However, for this it is important that higher education should be efficient, i.e. when it produces high outcomes with relatively low inputs.

As Petlák (1995) defined, the efficiency of the learning process means its usefulness and degree of achievement of set objectives in the process of teaching. The efficiency is most often associated with time (needed to achieve the set objectives - within the teaching unit, but also in relation to the length of school attendance), energy (spent by the teacher, as well as by the student, to achieve the objectives), results of teaching activities, their adequacy in relation to time and energy.

In measuring efficiency of higher education, it is generally important to account for the multi-product nature of educational production (Thanassoulis et al., 2011). This has been done in a number of previous studies in the higher education sector, e.g. in Stevens (2005).

According to Kováčováa and Vackováa (2015), the success of practical implementation of ideas of the education efficiency depends on certain factors: special methodical training of teachers, cooperation of teachers and students, provision of the necessary learning, material, moral and psychological conditions. The teacher is an important attribute of the efficiency of education and should:

- study new trends in the field of his own subject;

- pay attention to quality preparation of content and organization of education;

- follow the news and legislative development in the field;

- increase his own professional qualification and ensure his personal development;

- increase his didactic and pedagogical profile of competencies;

- actively participate in conferences and seminars, international workshops;

- follow professional and pedagogical publications;

- communicate with students;

- cooperate with institutions and organizations active in a particular field.

However, the efficiency of higher education systems depends not only on teachers. In many ways, it is determined by organization, institutional settings, location, funding structure, and other internal and external factors (Wolszczak-Derlacz, 2014).

The aim of this study is to measure the efficiency of higher education system in Republic of Srpska (RS) that is a part of Bosnia and Herzegovina $(\mathrm{B} \& \mathrm{H})$, which primarily relates to the success of studying.

\section{THE EDUCATION SYSTEM IN THE REPUBLIC OF SRPSKA}

The goal of the education system is to play a key role in the development of society through quality education, because quality education is a resource for the development of the economy and society as a whole. This will be achieved through openness towards other systems that can lead to creative thinking based on which young person will know how and where to find the appropriate information, how and when to use them. The task of the education system in the mentioned period should be to raise the creative and productive quality of the working age population, since every aspect of society's development is realized by people, so that the development of human resources should be the priority of the Republic, bearing in mind the negative rate of natural increase of the population, migration and an increasing share of the older population in the Republic of Srpska.

The Law on Higher Education of the Republic of Srpska, in accordance with the Bologna Declaration, established the principles of providing higher education in the Republic in accordance with European standards, such as: the principles of non-discrimination, the right to educa- 


\section{HIGHER EDUCATION INSTITUTIONS}

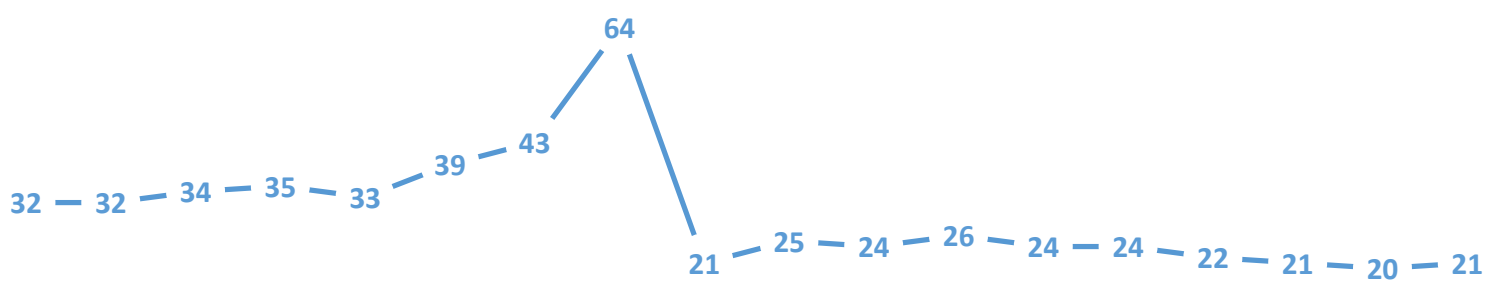

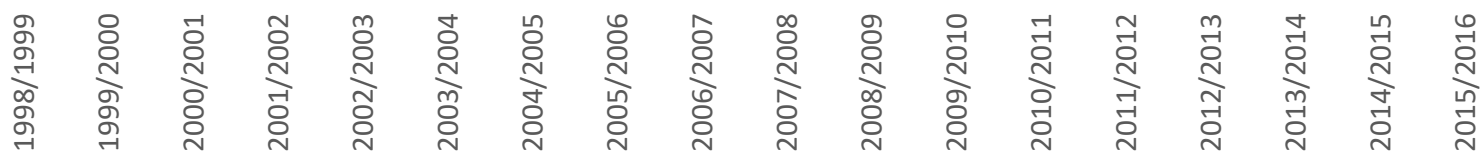

\section{Number of students, teachers and associates}

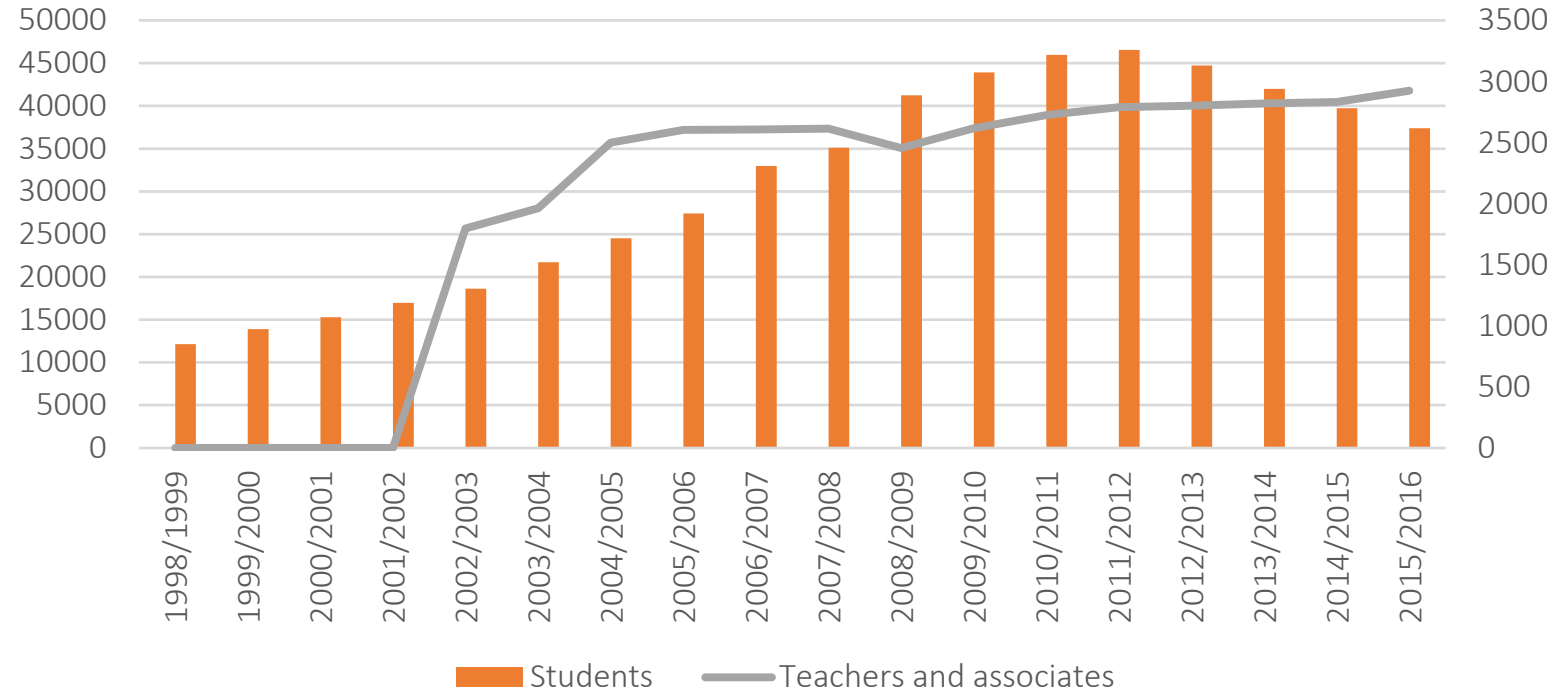

Figure 1. The number of higher education institutions, students, teachers and associates

tion, the autonomy of universities, the integrated university, the mobility of students and other academic staff, and the functioning of the authorities responsible for law enforcement and other standards. This Law envisages the implementation of four key principles of the Bologna Declaration: the introduction of a European credit transfer system - the ECTS, the introduction of a new structure of studies that consists of three cycles, the promotion of student and teacher mobility, and the adoption of system of comparable degrees.

Of the total number of licensed academic programs, the largest share (37\%) has study programs in the field of social sciences, business administration and law. On the other hand, the least licensed academic programs are in the fields of natural sciences and mathematics (6\%), and in agriculture, fishery, forestry and veterinary medicine (4\%) (Strategy, 2016).

The Law regulates higher education in $\mathrm{B} \& \mathrm{H}$ (Republic of Srpska part) in line with the Bologna Declaration and European standards. In the Republic of Srpska, twenty one higher education institutions were established: nine universities, two of which are public and seven private, twelve high schools, two of which are public and ten private. 
Source: Institute of Statistics of Republic of Srpska (2017).

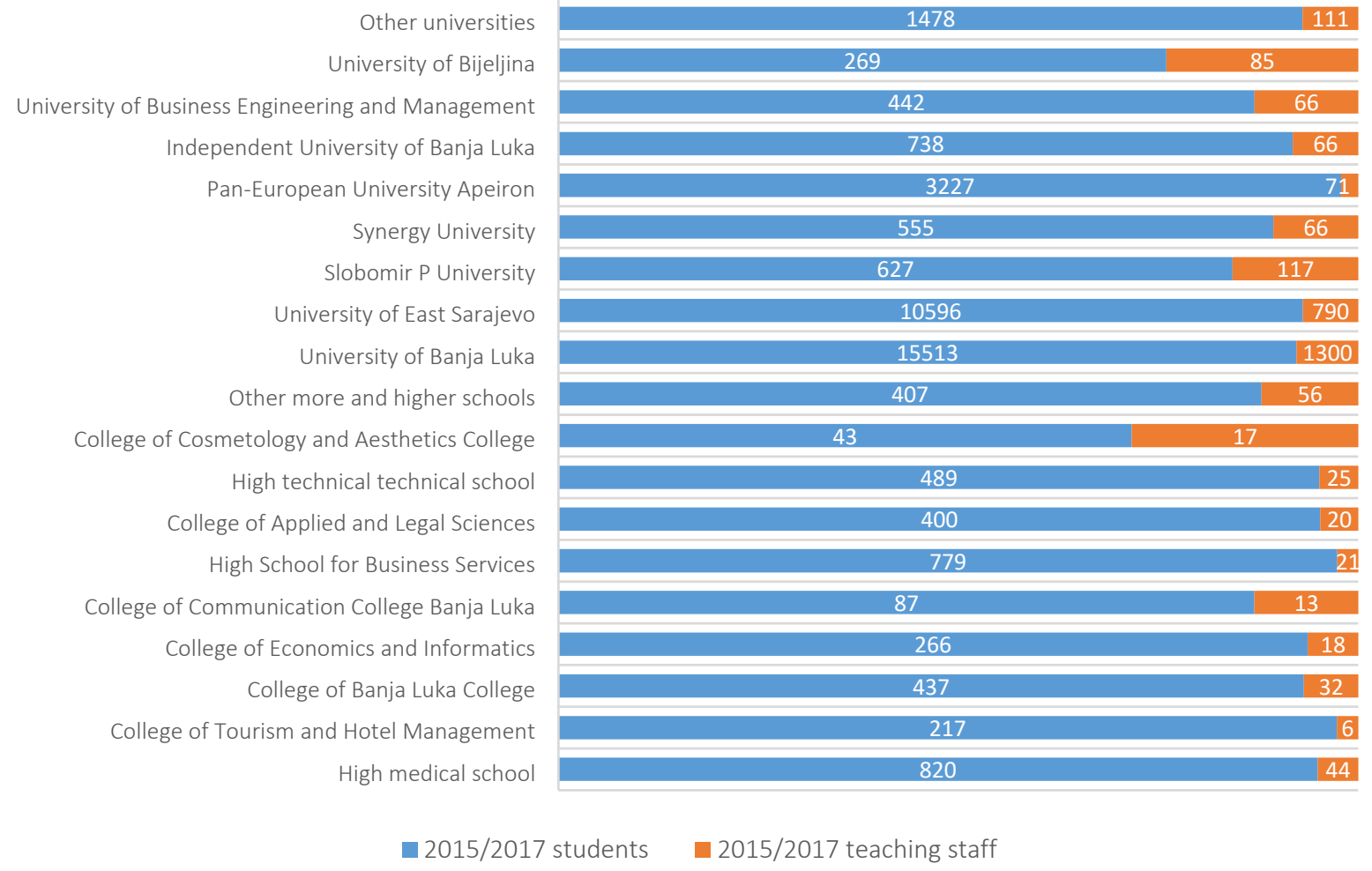

Figure 2. Students and teaching staff in RS universities

With the tendency to ensure the quality of work of higher education institutions, appropriate regulations have been established that stipulate the accreditation of higher education institutions and study programs. Accreditation is the process of determining the achieved level of quality in accordance with European standards in this field. For this reason, the Agency for Accreditation of Higher Education Institutions was established in 2011. The system of organization of the teaching process at most universities in the Republic envisages a duration of $4+1+3$ years, and high schools perform the first cycle of studies for three years and for a period of four years. At the University of Banja Luka, study programs were organized in cycles lasting from $4+1+3$ years and $3+2+3$ years. The second cycle of studies lasts one or two years, and the third cycle is organized after the second cycle and lasts for three years.

At public and private higher education institutions in the academic year 2014-2015, there were 41,033 students. Figure 3 gives an overview of the number of students in the academic year 2014-2015 by fields of education and makes evident that the stu- dents' interest in study programs in the field of social sciences is significantly expressed.

As Salmi (2009) wrote, one way of improving the university up to a world-class university is to use internationalization strategies effectively. Obviously, the multicultural dimension enriches the quality of the learning experience. Thereby, the current Strategy of Education Development of Republic of Srpska 2016-2021 (Strategy, 2016) emphasizes the necessity to implement a series of activities to strengthen staff and infrastructure capacities, increase student and staff mobility, achieve internationalization of the teaching and scientific research processes and increase the visibility of the domestic universities primarily in the regional and European, as well as the global academic community.

The following four strategic goals of the internationalization of the higher education in Republic of Srpska have been defined:

- internationalization of policies;

- internationalization of science; 
Enrolled students according to the field of education

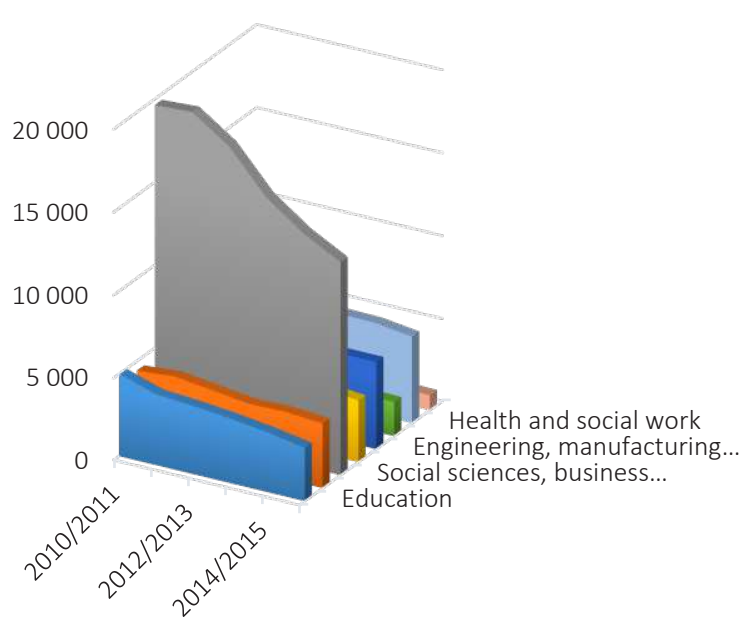

Education

Humanities and arts

Social sciences, business and law

Natural sciences, mathematics and informatics

Engineering, manufacturing technologies and construction

Agriculture

Health and social work
Graduated students according to the field of education

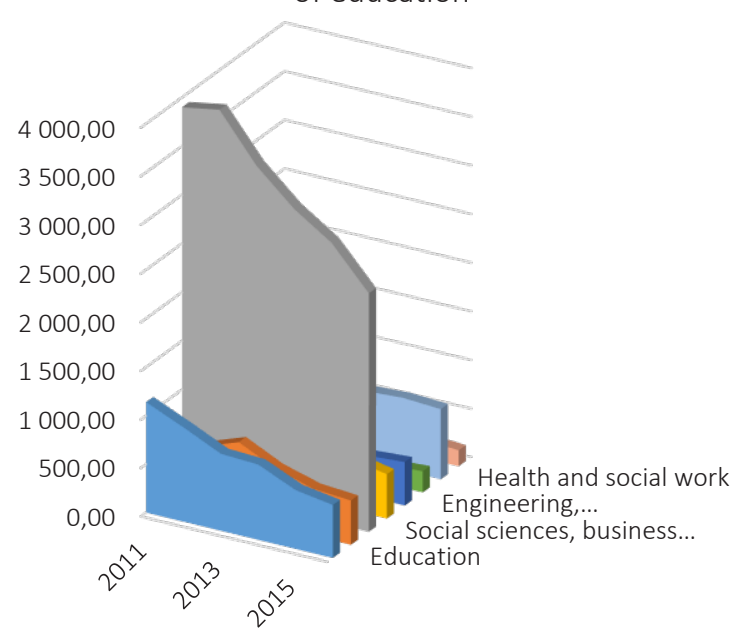

Education

- Humanities and arts

Social sciences, business and law

Natural sciences, mathematics and informatics

- Engineering, manufacturing technologies and construction

Agriculture

- Health and social work

Figure 3. Enrolled and graduated students according to the field of education

- internationalization of teaching;

- internationalization of the support system.

Regionally and internationally recognized study program is aimed at improving the quality of the study program and their internationalization, and increasing incoming mobility and implementing "internationalization at home":

- course units in English in already existing study programs, in accordance with the capacities of individual members, aimed at providing the possibility for a student to earn a minimum of 30 ECTS credits within a study program;

- introduction of "mobility windows" or "global windows" into curricula;

- utilization of open academic resources;

- $\quad$ introduction of English language courses in Ph.D. study programs;
- multidisciplinary/interdisciplinary study programs at the university level with the possibility of teaching in English, and later in other foreign languages, within available capacities;

- distinguished second and third cycle study programs (created according to the Salzburg Principles) at the regional and international level, with a focus on joint study programs and/or double/multiple majors;

- implementation of international standards in thesis supervision for the second and third cycle of studies in the segment of scientific research;

- $\quad$ increased outgoing and incoming mobility of students and staff;

- $\quad$ organization of student mobility as a mandatory segment of curricula and programmers in the form of attending classes, doing research or traineeship abroad for the first and second 
cycle of studies, i.e. teaching and research for the third cycle of studies;

- increased participation of students and staff of the university in exchange programs, such as the CEEPUS and Erasmus+ Key Action 1 - international credit mobility;

- engagement of distinguished scientists, professors and experts from prestigious universities as visiting lecturers;

- organization of Serbian language courses for foreign students to create the preconditions for the enrolment of foreign students to existing study programs at the university, and their introduction to Serbian history and tradition;

- increased cooperation with higher education institution, which offer study programs of Serbian language and literature;

- provide students with foreign language instruction in order to implement "internationalization at home" and increase outgoing mobility;

- increase internal mobility by continually educating staff and opening up resources, primarily course units, to all employees of the university;

- organization of lifelong learning courses using online platforms to ensure any required qualifications for the staff, as well as for the general population, in cooperation with partners abroad;

- organization of international cultural activities and creating international cultural contents.

The largest and most important program of mobility of students and academic staff of the EU member states is represented by the EU Program for Education, Training, Youth and Sports 2014-2020 (ERASMUS +), which includes teachers and students from the Republic. This is a new program financed by the EU (as of January 1, 2014), which represents the integration of European programs implemented by the European Commission in the period from 2007 to 2013: Lifelong Learning Program, "Jean Monet", "Youth in Action" Tempus, Erasmus Mundus, Alfa, Edulink and the Developed Industrial Countries Higher Education Program (Strategy, 2016).

According to the collected data (Institute of Statistics of Republic of Srpska, 2017), the number of enrolled students is lower every year.

The number of enrolled students in the school year 2010-2011 was 45,966, while that number in the school year 2015-2016 was 37,390. A smaller number of enrolled students is most prominent in the field of social sciences, business and law, where in the six-year period, there is a decline of 6,730 students. Education, humanities and arts also recorded a negative trend in the number of enrolled students. In the three scientific areas, there was a slight

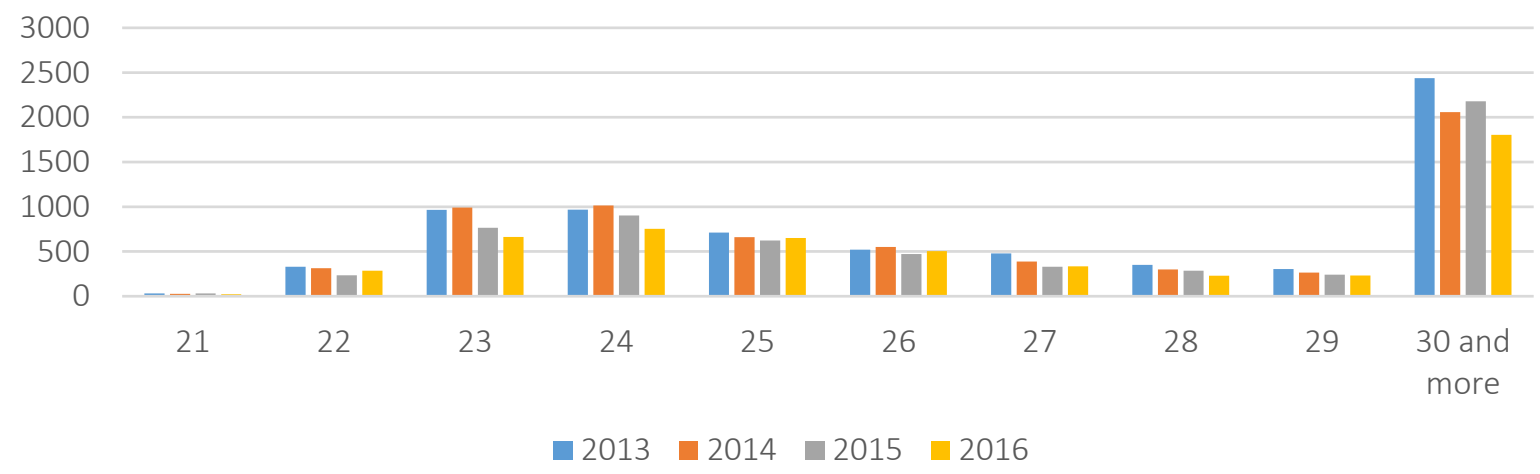

Figure 4. Graduated students per age 


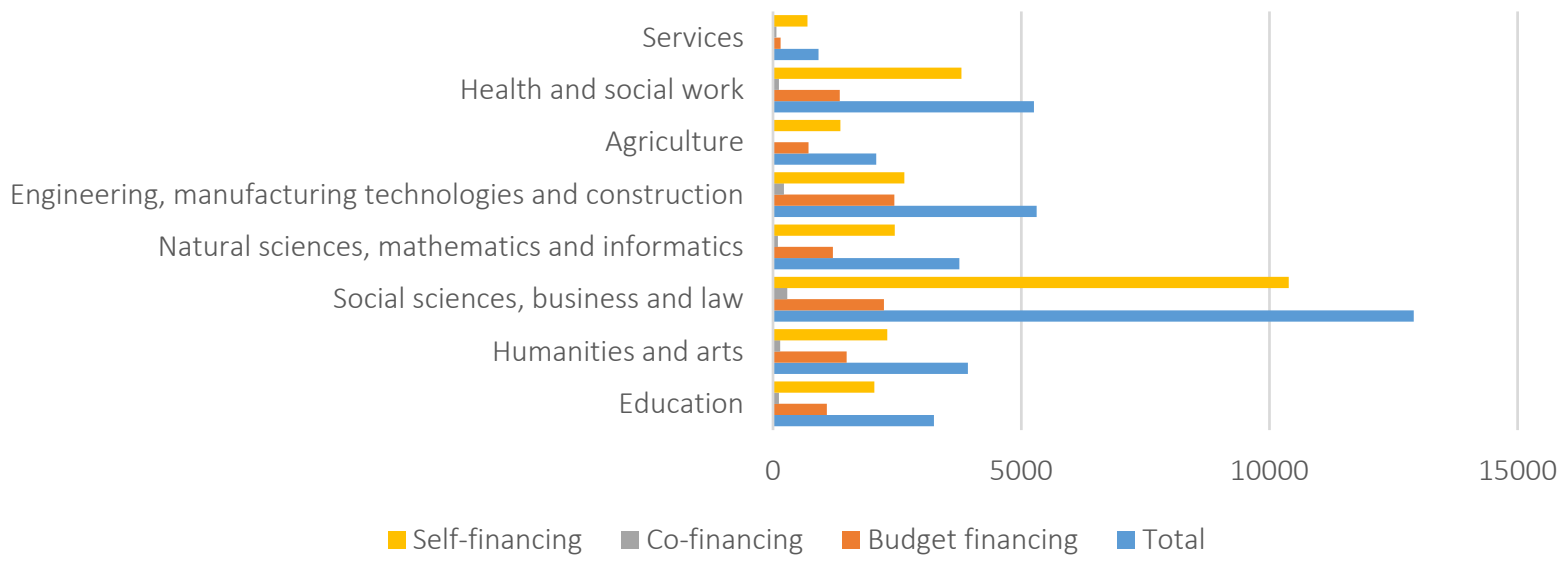

Figure 5. The number of students by scientific fields and according to the method of financing in the academic year 2015-2016

increase compared to the observed period. Health and social work recorded growth of 568 students in the last analyzed year compared to the initial year of observation. Also, in engineering, manufacturing, technologies and agriculture, students are more interested at the end of the observation period compared to the first year, which accounts for more than 433 and 99 students respectively.

Analogously to the trend that accompanies the number of enrolled students, the downward trend is evidenced by the number of graduated students. The number of graduated students in 2011 was 7,855 , while this number dropped in 2016 to 5,474. By analyzing the number of graduated students according to the scientific area, it is evident that the biggest drop was in the social sciences, business and law in 2011. There were 3,898 students and in $2016-2,454$ students. It is important to note that only in the field of agriculture, there was a small increase in the number of graduated students (50 students).

The age in which the largest number of students finishes their education is 30 years and more Almost $33 \%$ of students completed studies in this age category. In the category up to 22 years, there are only $5.5 \%$ of students who completed their regular studies in relation to the total number of students. In the age category up to 24 years, there are about $30 \%$ of students who completed their studies.
The age related to the completion of basic studies, in addition to financial possibilities, also determines the dependence of enrolment at the second and third cycles and continuation of education at the university. The analysis concerning the age of enrolled masters students and specialists shows that in the category up to 25 years, $24 \%$ of students were enrolled in the school year 2015-2016. In the category from 30 to 34 years, there are $15.5 \%$ of such students. The participation of students who decided to continue their education at a later age is about $5 \%$ compared to their total number.

As for the doctoral students, their maximum participation is in the age category up to 30 years $27.38 \%$, and then in the category from 30 to 34 years - $21.43 \%$, which confirms the fact that younger generations have dominant participation in the total number of doctoral students.

The total number of enrolled students in master and doctoral studies is presented in Figure 7, where it is evident that the number of enrolled master students increases year by year, while the number of doctoral students fluctuates over certain years.

From the data relating to the distribution of master and doctoral students according to scientific fields, it is evident that the second and third cycle of studies are followed by the selection of the scientific field of students of the first cycle. Thus, RS has the largest 
Source: Institute of Statistics of Republic of Srpska (2017).

Enrolled in masters and specialist studies by age in school year 2015/2016

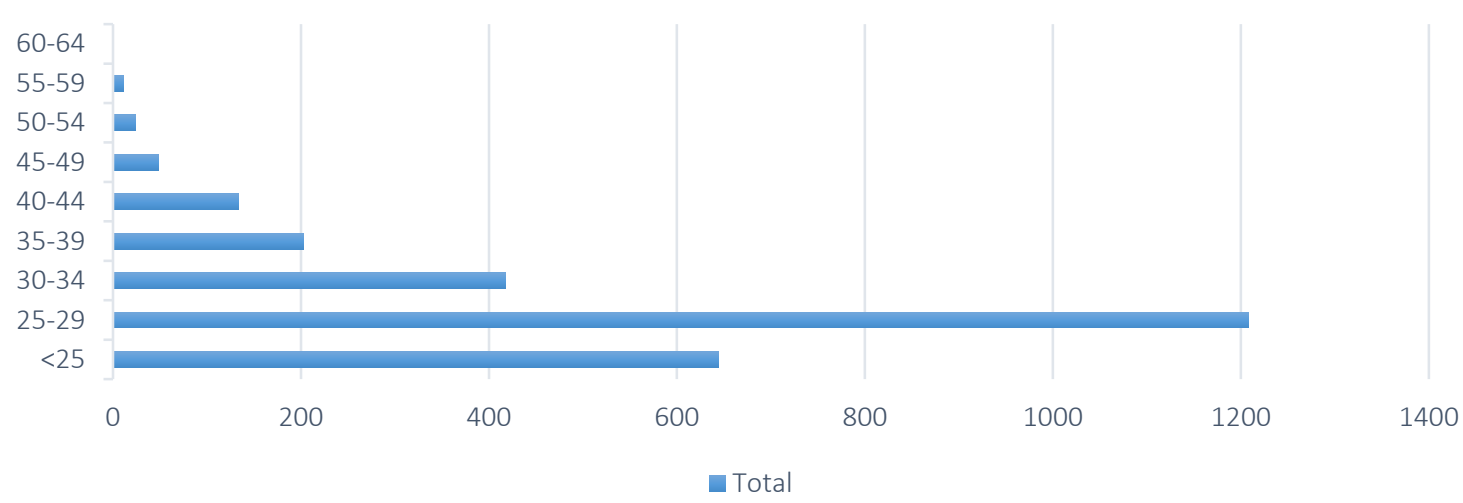

Doctoral students by the age in the school year 2015/2016

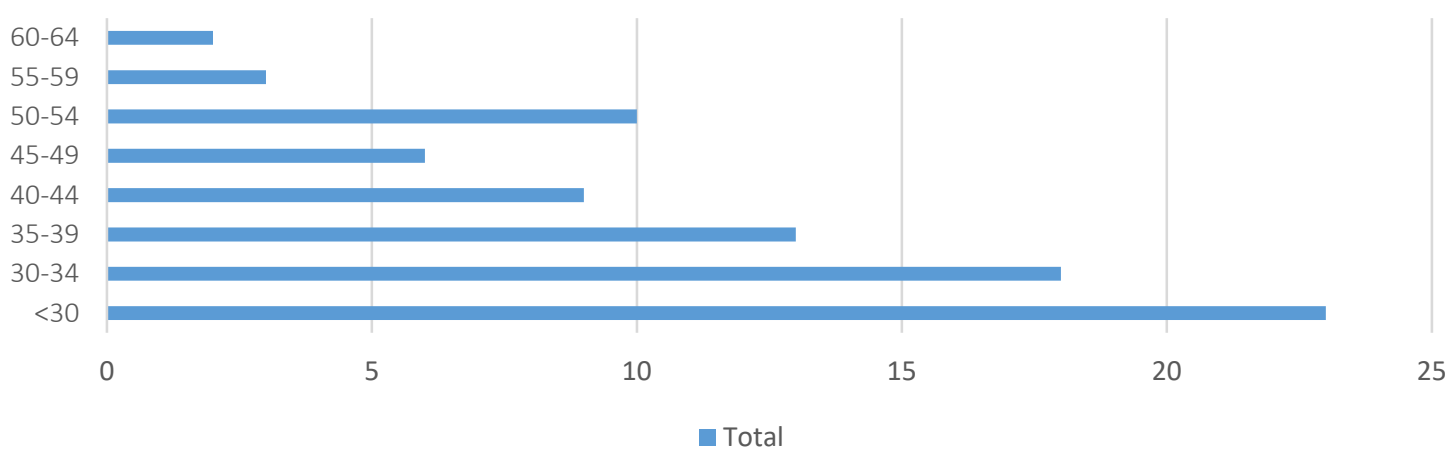

Figure 6. Enrolled in masters, specialist and doctoral studies by their age

Source: Institute of Statistics of Republic of Srpska (2017).

Enrolled in master and specialist studies

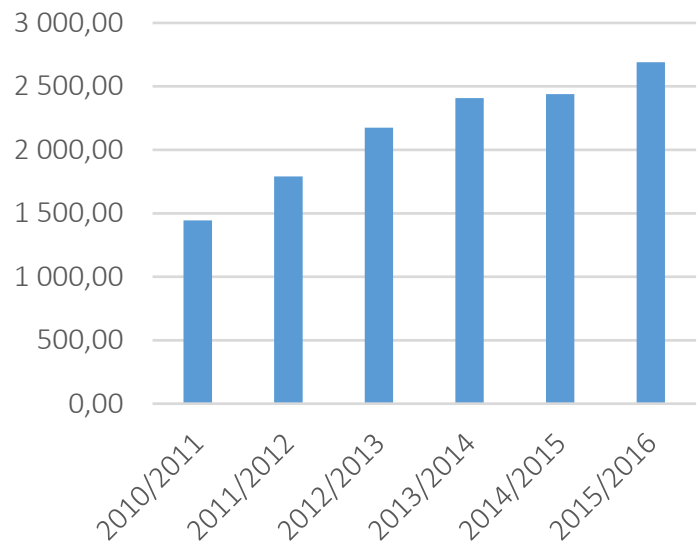

Doctorates

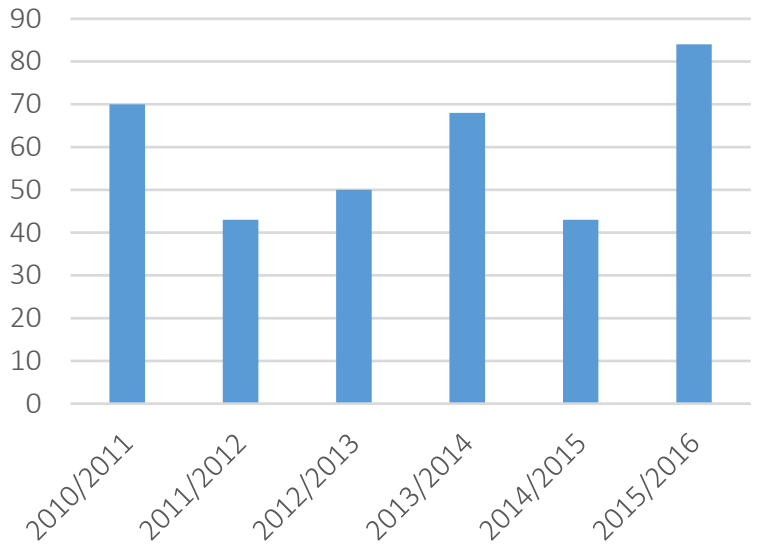

Figure 7. Enrolled in masters and specialist studies and doctoral studies

number of master and doctoral students in the field The described trends in the development of highof social sciences $38.79 \%$ and $48.94 \%$, respectively. In er education system of B\&H are somewhat conthe second place are Medical and Health Sciences tradictory. On the one hand, the number of stuwith $18.55 \%$ masters of science, masters and special- dents of the master's programs (see Figure 7) and ists compared to their total number. teachers (see Figure 1) is growing. But on the other 

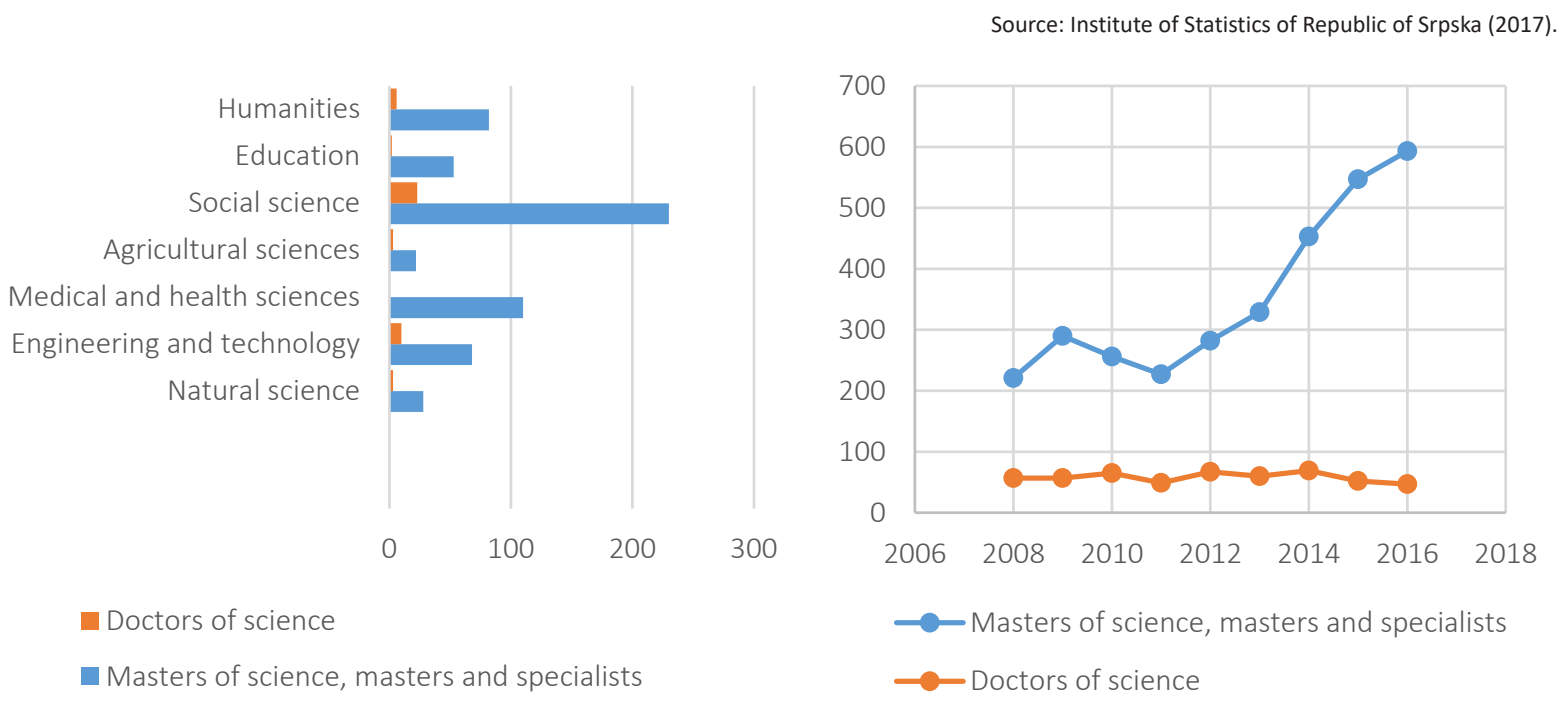

Figure 8. Masters of science, masters, specialists and doctors of science according to the scientific area (2016) and for the period 2006-2018

hand, the total numbers of students and institutions have been declining for the past 6 years (see Figure 1). Probably, such strengthening of teaching staff and the growing share of the magistracy should improve the efficiency of the education system.

Therefore, we decided to test the hypothesis of the growing efficiency of the higher education system of $\mathrm{B} \& \mathrm{H}$. Besides, we are interested, which of the fields in this system are the most and the least effective.

So, in this study, we will try to answer on the following questions:

How efficient are the main fields of higher education system in Bosnia and Herzegovina?

Is the efficiency of the higher education system in Bosnia and Herzegovina growing with growing number of graduates and teachers, and shrinking number of institutes?

\section{LITERATURE REVIEW}

There are a lot of publications regarding measuring the efficiency in higher education. Therein, the efficiency measurement implies the selection and availability of appropriate data, measures and method. We turned to research literature to make the right choice.
The concept of efficiency presents process of establishing the relationship between inputs and outputs. In the education sector, the production process is characterized by multiple inputs and multiple outputs. The educational sector is defined as 'efficient' when it is not possible to produce more of some outputs without reduction in the production of the other outputs. Using different allocation of the inputs can produce more of some outputs, and can also lead to lower production of some of the other outputs.

According to Kuah and Wong (2009), there is no definitive standard to guide the inputs/outputs selection in university efficiency measurement.

Ahn et al. (1989) selected faculty salaries, state research funds, administrative overheads, and total investment in physical plants as inputs and number of undergraduate enrolments, number of graduate enrolments, total semester credit hours, and federal and private research funds as outputs.

The rationale for substituting "achievable output/ outcome" (that an effective and efficient organization can generate if all the potentially usable resources were deployed and utilized in pursuit of the objectives of the organization) for the actual targeted objectives of the organization is that the measurement of relative efficiency should be independent of any systematic biases in judgments that organization may make in selecting their targeted levels of output (Mensah, Lam, \& Werner, 2005). 
According to Johnes (2006), the quantity and quality of undergraduates, number of postgraduates, number of teaching and research staffs, administration expenditures, library and computer facility expenditures, and value of interest payments and depreciations are inputs and quantity and quality of first degree graduates, number of higher degree graduates, and research grants as outputs.

By solving the objective function using linear programming, it is possible to determine the efficiency curve called also the production frontier, which covers all the most efficient units of the focus group. The graphical presentation of the efficiency curve is possible for models: 1 input and 1 output, 2 inputs and 1 output, or 1 input and 2 outputs. In the case of multidimensional models, the curve equivalent incorporates a few fragments of different hyperplanes linked to each other. Objects are believed to be technically efficient if they are located on the efficiency curve (Pietrzak et al., 2016).

Zhang and Luo (2016) explained the expansion of the scale of higher education, but at the same time that the higher education of the country should take the road to the development of connotation, strengthen macro-control of the higher education, and concluded that it makes the scale of education more in line with the development of the national economy, further implement the strategy of rejuvenating the country through science and education, speed up the reform of higher education system, created more favourable conditions for the development of higher education, the quality and efficiency of higher education.

The relationship among the different inputs and outputs of the educational process is called the education production function. Education production functions examine the influence of various input factors on student efficiency. According to Webbink (2012), it is important to note that inputs of the education process not only include financial resources, but also factors such as the social background, ability and educational history of the students.

Technical inefficiency is a measure of the realized school production versus the maximum of the school production conditional on the budget (Blank, Hulst, \& Koot, 2007).
As Goncharuk (2016) found, stochastic frontier analysis (SFA) and data envelopment analysis (DEA) are the most appropriate methods for measuring the efficiency of higher education. However, SFA is more appropriate if we have only one output, need to decompose efficiency into main components and need to model the influence of various factors on higher education institutions' efficiency. In other cases, the DEA is better for measuring efficiency. However, in order to use DEA for HEIs efficiency analysis, we have to be sure that our sample has enough data and this data does not have errors.

DEA is a non-parametric frontier method, first offered by Charnes et al. (1978) that has received wide theoretical development and practical application for the last decade in a management of various fields of human activity, for example, in water utilities (Lo Storto, 2014), banking and investments, postal service (Çakır et al., 2015), healthcare and pharmaceuticals (Lo Storto \& Goncharuk, 2017), education (De Witte, 2015), manufacturing (Goncharuk \& Figurek, 2017), energetics (Goncharuk \& Lo Storto, 2017), etc. Its essence consists in use of methods of linear programming for construction of a piecewise linear convex surface (frontier) for enterprises sample, and estimation of efficiency concerning this surface.

The DEA presents an important tool in the comparative efficiency worldwide in higher education institutions (Agasisti \& Johnes, 2009; Thanassoulis \& Dunstan, 1994; Worthington, 2001; Taylor \& Bains, 2004).

In order to measure the efficiency of 45 Canadian universities using 1992-1993 data, McMilan and Datta (1998) used DEA and they constructed nine models, which differ in inputs (the number of faculties, total costs, other costs, etc.) and in outputs (the number of graduates, the number of doctoral level graduate students, research quantum, etc.).

Measuring the efficiency of 72 German universities for the period 1998-2003, Kempkes and Pohl (2007) used the number of graduates and the amount of research grants as outputs and the research and technical staff. 
Mikusova (2015) took the following variables: the number of academic staff and other costs as inputs and the number of bachelor and master graduates, the number of $\mathrm{PhD}$ graduates, the number of bachelor and master students and the number of $\mathrm{PhD}$ students as outputs.Therefore, based on the experience of previous efficiency measurements and recommendations, in particular by Goncharuk (2016), DEA is the most appropriate method for measuring an efficiency of higher education system.

\section{METHODOLOGY}

Based on the rational approach in selecting and analyzing the structure of inputs and outputs, with the aim of perceiving the success and determining the efficiency of completing the studies, the authors decided to use the enrolled students according to the field of education, budget financing, co-financing, self-financing as inputs, while the number of the graduated students according to the field of education was used as output.

As the most appropriate efficiency measurement method for higher education, the DEA was used to get efficiency scores for 8 main fields of high education in B\&H, partly referring to RS. For a complete ranking and identification of the most efficient fields of high education, the DEA model of super-efficiency was used.

Among existing DEA models in the context of given study, it is expedient to use the following:

1) to estimate an efficiency score using the common input-oriented model with a constant return of scale (CRS model form) (see Charnes et al., 1978);

2) to make full ranking using the DEA model of super-efficiency, offered by Anderson and Petersen (1993).

Mathematically the input-oriented DEA model of super-efficiency for $m$ inputs, $r$ outputs and $n$ decision-making units (DMUs) can be formalized in the following way:

$$
\min z=\theta^{\mathrm{Sup}} \text {, subject to: }
$$

$$
\begin{aligned}
& \sum_{j=1, \neq q}^{n} x_{i j} \lambda_{j}+s_{i}^{-}=\theta^{\text {sup }} x_{i q}, i=1,2, \ldots, m, \\
& \sum_{j=1, \neq q}^{n} y_{i j} \lambda_{j}-s_{i}^{+}=y_{i q}, i=1,2, \ldots, r, \\
& \lambda, s^{-}, s^{+} \geq 0,
\end{aligned}
$$

where $\theta^{\text {sup }}$ is a scalar, $\lambda$ is a weight of DMU $j$, $x_{j}, y_{j}$ are inputs and outputs of DMU $j, s_{i}^{-}, s_{i}^{+}$ are input and output slacks.

With DEA method, it is possible to generate a relationship between output and input in order to characterize the efficiency of education.

Further, to trace an efficiency trend, we examined the scientific publication activity in RS for 7 years by types of research: fundamental, applied, and developmental.

In addition, the results of scientific productivity of RS with total B\&H and neighbouring Balkan countries like Serbia, Slovenia and Croatia were compared to explore the contribution of the research component in the efficiency of the higher education system of RS, and clarify the international aspect of the relative efficiency of $\mathrm{B} \& \mathrm{H}$ higher education system.

\section{THE DATA}

The descriptive statistics of a sample of collected data on the main fields of higher education in RS is framed in Table 1.

Table 1. Descriptive statistics for a sample

Source: Authors' calculations based on universities reports.

\begin{tabular}{l|c|c|c}
\hline \multicolumn{1}{c|}{ Variables } & Mean & Median & $\begin{array}{c}\text { Stand. } \\
\text { dev. }\end{array}$ \\
\hline $\begin{array}{l}\text { Enrolled students according to } \\
\text { the field of education, people }\end{array}$ & 4,674 & 3,840 & 3,642 \\
\hdashline Budget financing, 000 EUR & 1,332 & 1,274 & 748 \\
\hline $\begin{array}{l}\text { Co-financing, 000 EUR } \\
\text { Self-financing, 000 EUR }\end{array}$ & 133 & 120 & 86 \\
\hline $\begin{array}{l}\text { Graduated students according } \\
\text { to the field of education, } \\
\text { people }\end{array}$ & 3,209 & 2,376 & 3,041 \\
\hline
\end{tabular}

Total number of observed main fields of education is 8 . The sample covers all the universities of the Republic of Srpska for 2015. The total number of graduated students for all the observed main fields of education was 5.5 thousand people. 


\section{RESULTS}

Using DEA, the following efficiency scores for every field of higher education were obtained (Table 2).

Table 2. DEA results

\begin{tabular}{l|c}
\multicolumn{1}{c}{$\begin{array}{c}\text { Main fields of higher } \\
\text { education in RC }\end{array}$} & $\begin{array}{c}\text { Source: Authors' calculation. } \\
\text { Input-oriented CRS } \\
\text { super efficiency scores }\end{array}$ \\
\hline Agriculture & 2,31935 \\
\hline Social sciences, business and law & 1,84187 \\
\hline Education & 1,13531 \\
\hline Services & 0,99770 \\
\hline Health and social work & 0,79424 \\
\hline $\begin{array}{l}\text { Natural sciences, mathematics and } \\
\text { informatics }\end{array}$ & 0,75111 \\
\hline Humanities and arts & 0,74066 \\
\hline $\begin{array}{l}\text { Engineering, manufacturing } \\
\text { technologies and construction }\end{array}$ & 0,63230 \\
\hline
\end{tabular}

Basing on the DEA results, it is evident that the science field "agriculture" have achieved the highest efficiency score. Social sciences, business and law and education are also efficient relatively. However, engineering, manufacturing technologies and construction field has the lowest efficiency score. The later consumes the highest budget, but gets the lowest results.

Agriculture in the Republic of Srpska occupies a significant place in its economic structure. The share of agriculture in the gross domestic product is $8.9 \%$. Although only 3,000 are formally emploed, informal (permanent or temporary) employment in agriculture is much higher. Rural areas occupy about 95\% of the territory of the Republic of Srpska and there live about $83 \%$ of its population (Strategic Plan, 2015). Apparently, it is not by chance that the training of specialists in this particular sector of the economy has the highest efficiency, since it is agriculture that is developing at the highest rates (Statistical Report, 2018).

The efficiency of higher education, taking into account all the scientific fields, encompasses academic and professional work and the quality of teaching, research, student results and the success of graduates.

In order to identify the factors that influence the improvement of the achieved student results, and the strengthening of the quality of teaching and the entire education system, higher education institutions are obliged to improve self-evaluation procedures and engage employees and students in the continuous improvement of the teaching process, and based on the principle "student in the learning center". The unity of the internal and external quality assurance system is achieved by implementing the Standards and Guidelines for Quality Assurance in the European Standards and Guidelines (ESG).

The work of higher education teacher must be basically a scientific research activity, as well as the transfer of knowledge, informed scientific truths, teaching, learning, leading the student to the knowledge necessary for his professional engagement, for continuous improvement. Therefore, a teacher in a higher education institution must at the same time possess the competences of lecturers, teachers, educators, mentors, scientists and researchers with references.

Higher education needs to be directed towards the European educational framework through the application of European standards in education. The level of achieving these standards can only be measured by a set of European indicators implemented in the statistical education system.

Improving the professional, professional and scientific competences of university teachers can be realized through the following activities:

- define the criteria for measuring the pedagogical work of university teachers;

- provide provisions in the normative acts of higher education institutions, in which the criteria for determining pedagogical competencies will be concretized;

- perform periodic self-assessment and external evaluation of pedagogical, didactic-methodical and research qualities of university teachers;

- establish a system of continuous professional training in the direction of further development of functional and multidisciplinary competences of university teachers; 
600
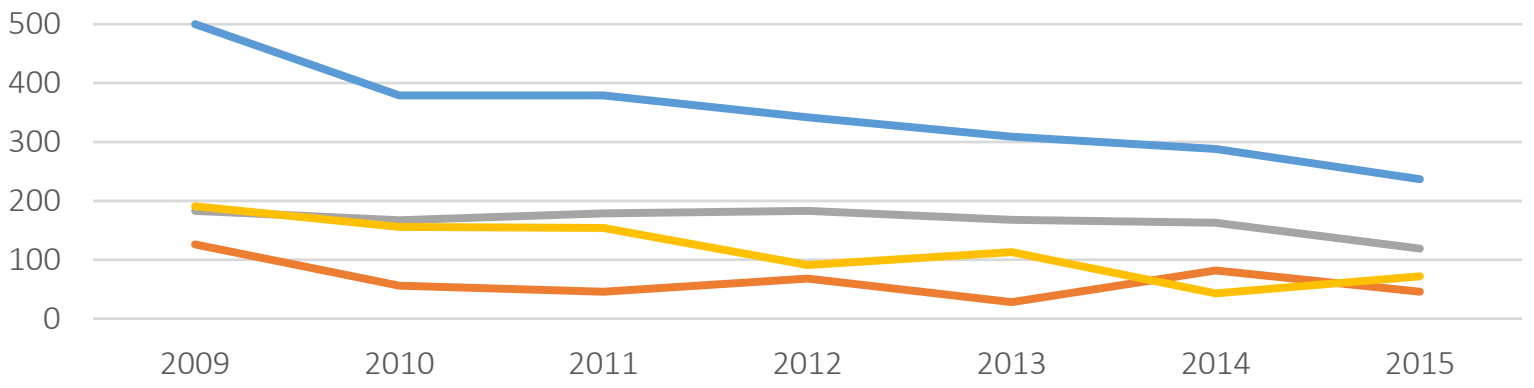
Total - Fundamental Applied Developmental

Figure 9. Number of research and development works published in Republika Srpska during the period 2009-2015

- $\quad$ introduce mandatory evaluations and reviews of scientific research work and results of this work according to internationally recognized standards and with the participation of international experts;

- $\quad$ increase the number of scientific publications and papers in recognized journals;

- define the system of internal and external evaluation of scientific and research work at universities and teaching-scientific process;

- to achieve cooperation within the EU's research and development programs;

- $\quad$ increase the number and participation of visiting scientists from abroad in the teaching process.

Primary responsibility for the implementation of these processes is provided by higher education institutions with the obligation to publish the results of the work, which will additionally ensure the quality of higher education.

According to the data of the Republic Bureau of Statistics, 2,434 papers were published between 2009 and 2015 (Figure 9).

The most published works were applied research (1.162), developmental research (820), and the least fundamental research (452). However, the downward trend in the total number of publications indicates a twofold deterioration in the scientific efficiency of Bosnia and Herzegovina for the sixyear period.

Comparison with neighbouring countries showed that scientific efficiency in the B\&H is much smaller than the scientific productivity of the countries in the region (Table 3 ).

Table 3. Total number of WoS papers, quotations and citations from 2010 to 2014.

Source: Ministry of Science RS, Strategy of Education Development of Republic of Srpska 2017-2021.

\begin{tabular}{l|c|c|c}
\hline $\begin{array}{c}\text { Country/ } \\
\text { Region }\end{array}$ & $\begin{array}{c}\text { Number of WoS papers } \\
\mathbf{( M}_{\mathbf{2 0 1 0 - 2 0 1 4}} \mathbf{M}_{\mathbf{2 0 1 0 - 2 0 1 2}} \mathbf{)}\end{array}$ & $\begin{array}{c}\text { No. of citations of WoS papers } \\
\mathbf{( M}_{\mathbf{2 0 1 0 - 2 0 1 4}} \mathbf{M}_{\mathbf{2 0 1 0 - 2 0 1 2}} \mathbf{)}\end{array}$ & $\begin{array}{c}\text { No. of WoS citations } \\
\mathbf{( M}_{\mathbf{2 0 1 0 - 2 1 4}} \mathbf{M}_{\mathbf{2 0 1 0 - 2 0 1 2}} \mathbf{)}\end{array}$ \\
\hline Serbia & $31,679(6,335.8,6,141.67)$ & $17,206(3,411.2,3,762.67)$ & $119,979(23,995.8,31,353.0)$ \\
\hline Croatia & $23,452(4,690.4,4,696.0)$ & $13,020(2,604.0,2,944.33)$ & $114,763(22,952.6,31,340.67)$ \\
\hline Slovenia & $23,215(4,643.0,4,633.67)$ & $14,640(2,928.0,3,128.67)$ & $128,949(25,789.8,34,436.67)$ \\
\hline $\begin{array}{l}\text { Republic of } \\
\text { Srpska }\end{array}$ & $780(156.0,151.33)$ & $301(60.2,69.0)$ & $1,161(232.2,294.0)$ \\
\hline $\begin{array}{l}\text { Federation } \\
\text { B\&H }\end{array}$ & $2,537(507.4,554.33)$ & $1,041(208.2,247.67)$ & $5,943(1,188.6,1,611.0)$ \\
\hline Total B\&H & $3,265(653.0,695.33)$ & $1,320(264.0,311.67)$ & $7,047(1,409.4,1,893.0)$ \\
\hline
\end{tabular}


In 2015 , only 237 scientific research papers were published in RS, the largest number of the papers belongs to applied research (50.2\%), developmental research (30.4\%) and fundamental research (19.4\%). In the period from 2010 to 2014, researchers from the RS published 780 papers (Web of Science), 301 of which were cited, and 1,161 citations were regis- tered in total. This confirms relatively low scientific efficiency of Bosnia and Herzegovina.

Thus, declining indicators of scientific efficiency does not confirm the hypothesis about the deterioration of the efficiency of higher education system in Bosnia and Herzegovina.

\section{CONCLUSION AND RECOMMENDATIONS}

Considering the relative efficiency of main fields of the higher education system of Bosnia and Herzegovina, we found that agriculture is the most efficient field of higher education in this country. However, the engineering, manufacturing technologies and construction has the lowest efficiency score, because they consume the highest budget, but get the lowest results.

However, the efficiency of higher education should taking into account all the scientific fields, and encompasses academic and professional work and the quality of teaching, research, student results and the success of graduates.

The hypothesis of the growing efficiency of the higher education system of $\mathrm{B} \& \mathrm{H}$ was not confirmed. The downward trend in the total number of publications indicates a twofold deterioration in the scientific efficiency of Bosnia and Herzegovina for the six-year period.

Comparison with neighbouring countries showed relatively low scientific efficiency of Bosnia and Herzegovina.

All this indicates that currently the higher education system in Bosnia and Herzegovina is relatively inefficient and its efficiency falls down.

The number of graduates in the field of social sciences and humanities is on the rise, while in natural sciences, it is decreasing. In the coming period, it is necessary to change the trend of decline in the number of graduates from study programs in the fields of natural sciences and mathematics, engineering, technology and construction, because the personnel from these areas are the driving force of the economic and social development.

It is necessary to enable students to continually improve and to constantly modernize their professional competences. Modernization of study programs means that the concept of teaching/learning is scientifically based (in accordance with the latest scientific achievements and knowledge of the profession, psychology of learning, psychology of development and motivation, and teaching methods), that it is flexible, that the teacher, teacher and expert associate can successfully adapt new trends in education and perfect it according to the news that will be necessary for the future.

Measurement of competency requires the establishment of European indicators in the system of assessment and selection of higher education staff. In order to provide competent teaching staff, a system of new education is crucial, both in basic studies and in professional development. Improving the university teaching process next measures can be implemented through the following activities:

- improve the legal framework of higher education through upgrading existing ones and introducing new standards in the field of scientific education; 
- equalize minimum criteria and procedures for selection in scientific titles;

- increase the number of teachers who actively speak English and use modern technolo gies in work;

- introduce the mandatory presentation and discussion of scientific research projects in the field;

- establish an adequate system of scoring of subjects and evaluation of extra-curricular activities of students;

- $\quad$ adopt criteria for writing and publishing scientific papers and teaching textbooks.

In addition to the inadequate institutional framework, primarily in the field of elections to higher scientific and scientific institutions, the second most important reason for this situation is insufficient investment in research and development. As a rule, insufficient scientific and technological transfer is mainly a consequence of modest investments in research and development, or the protection of intellectual property.

The achievement of the international pre-qualification of the higher education system of $\mathrm{B} \& \mathrm{H}$ and the positioning of its higher education institutions, without delay, should be set as one of the priority activities of bodies and institutions in the field of higher education.

\section{REFERENCES}

1. Agasisti, T., \& Johnes, G. (2009). Beyond frontiers: comparing the efficiency of higher education decision-making units across more than one country. Education Economics, 17(1), 59-79. https://doi. org/10.1080/09645290701523291

2. Ahn, T., Arnold, V., Charnes, A., \& Cooper, W. W. (1985). DEA and Ratio Efficiency Analyses for Public Institutions of Higher Learning in Texas. In J. L. Chan, \& J. M. Patton (Eds.), Research in Governmental and Nonprofit Accounting, 5, (pp. 165-185). JAI Press.

3. Andersen, P., \& Petersen, N. C. (1993). A Procedure for Ranking Efficient Units in Data Envelopment Analysis. Management Science, 39(10), 1261-1264. Retrieved from https:// www.jstor.org/stable/2632964

4. Blank, J., Van Hulst, B., \& Koot, P. (2007). Basisonderwijs en bureaucratie (Primary education and bureaucracy. IPSE, University of Delft.

5. Charnes, A., Cooper, W., \& Rhodes, E. (1978). Measuring the efficiency of decision making units. European Journal of Operational Research, 2(6), 429444. https://doi.org/10.1016/03772217(78)90138-8

6. De Witte, K. (2015). Contemporary Economic Perspectives in Education. Leuven: Leuven University Press.

7. Goncharuk, A. G. (2016). Evaluating the Efficiency of Higher Education. Journal of Applied Management and Investments, 5(2), 82-91. Retrieved from http://www.jami.org.ua/ Papers/JAMI_5_2_82-91.pdf

8. Goncharuk, A. G., \& Figurek, A. (2017). How efficient is winemaking in Eastern Europe? New Medit, 16(2), 64-72. Retrieved from https://newmedit. iamb.it/share/img_new_medit articoli/1104_64concharuk.pdf

9. Goncharuk, A. G., \& Lo Storto, C. (2017). Challenges and policy implications of gas reform in Italy and Ukraine: evidence from a benchmarking analysis. Energy Policy, 101, 456-466. https://doi. org/10.1016/j.enpol.2016.10.037

10. Government of Republic of Srpska (2015). Strategic Plan for
Development of Agriculture and Rural Areas of the Republic of Srpska 2016-2020. Banja Luka.

11. Institute of Statistics of Republic of Srpska. (2017). Higher Education Statistical bulletin, No. 14 .

12. Johnes, J. (2006). Data Envelopment Analysis and Its Application to the Measurement of Efficiency in Higher Education. Economics of Education Review, 25(3,) 273-288. https://doi.org/10.1016/j.econedurev.2005.02.005

13. Kempkes, G., \& Pohl, C. (2007). The Efficiency of German Universities - Some Evidence from Non-Parametric and Parametric Methods (CESifo Working Paper). https://doi. org/10.1080/00036840701765361

14. Kováčováa, L., \& Vackováa, M. (2015). Applying Innovative Trends in The Process of Higher Education Security Personnel in Order to Increase Efficiency. Procedia - Social and Behavioral Sciences, 186, 120-125. http:// dx.doi.org/10.1016/j.sbspro.2015.04.085 
15. Kuah, C. T., \& Wong, K. Y. (2011). Efficiency assessment of universities through data envelopment analysis. Procedia Computer Science, 3, 499506. https://doi.org/10.1016/j. procs.2010.12.084

16. Lo Storto, C. (2014). Benchmarking operational efficiency in the integrated water service provision: Does contract type matter? Benchmarking: An International Journal, 21(6), 917943. https://doi.org/10.1108/BIJ11-2012-0076

17. Lo Storto, C., \& Goncharuk, A. G. (2017). Efficiency vs Effectiveness: A Benchmarking Study on European Healthcare Systems. Economics and Sociology, 10(3), 102-115. http:// dx.doi.org/10.14254/2071789X.2017/10-3/8

18. McMilan, M. L., \& Datta, D. (1998). The Relative Efficiencies of Canadian Universities: A DEA Perspective. Canadian Public Policy, 24(4), 485-511.

19. Mensah, Y. M., Lam, K, C., \& Werner R. (2005). An Approach to Evaluating Relative Effectiveness in Non-Profit Institutions. SSRN Electronic Journal. Retrieved from https://www.academia. edu/32205176/An_Approach_to_ Evaluating_Relative_Effectiveness_ in_Non-Profit_Institutions

20. Mikusova, P. (2015). An Application of DEA Methodology in Efficiency Measurement of the Czech Public Universities. Procedia Economics and Finance, 25, 569-578.

21. Ministry of science RS (2016). Strategy of scientific and technological development of Republic of Srpska, 2017-2021.

22. OECD (2015). Innovating Education and Educating for Innovation. The power of digital technologies and skills. https://doi. org/10.1787/9789264265097-en

23. Petlák, E. (1995). Možnosti zefektívnenia výchovnovzdelávacieho procesu. In Technológia vzdelávania tretieho tisícročia. Zborník $z$ vedeckej konferencie (142 p).
24. Pietrzak, M., Pietrzak, P., \& Baran, J. (2016). Efficiency assessment of public higher education with the application of Data Envelopment Analysis: The evidence from Poland. Online Journal of Applied Knowledge Management, 4(2), 59-73. Retrieved from http:// www.iiakm.org/ojakm/articles/2016/volume4_2/OJAKM_ Volume4_2pp59-73.pdf

25. Salmi, J. (2009). The Challenge of Establishing World-Class Universities. Washington: The World Bank. Retrieved from http://siteresources.worldbank.org/EDUCATION/ Resources/278200-1099079877269/547664-1099079956815/547670-1237305262556/ WCU.pdf

26. Statistical Report (2018). Annual Statistical Report. Statistical Office of the Republic of Srpska: Banja Luka.

27. Stevens, P. A. (2005). A stochastic frontier analysis of English and Welsh universities. Education Economics, 13(4), 355-374. https://doi. org/10.1080/09645290500251581

28. Strategy (2016). Strategy of Education Development of Republic of Srpska 2016-2021. Government of Republic of Srpska, Banja Luka.

29. Taylor, J., \& Bains, C. (2012). Performance management in UK universities: Implementing the balanced scorecard. Journal of Higher Education Policy and Management, 34(2), 111-124. https://doi.org/10.1080/136008 0X.2012.662737

30. Thanassoulis, E., \& Dunstan, P. (1994). Guiding schools to improved performance using data envelopment analysis: An Illustration with Data from a Local Education Authority. Journal of the Operational Research Society, 45(11), 1247-1262. https:// doi.org/10.1057/jors.1994.198

31. Thanassoulis, E., Kortelainen, M., Johnes, G., \& Johnes, J. (2011). Costs and efficiency of higher education institutions in England: a DEA analysis. Journal of the operational research society, 62(7), 1282-1297. https://doi. org/10.1057/jors.2010.68

32. Universities UK (2011). Efficiency and effectiveness in higher education: A report by the Universities UK Efficiency and Modernisation Task Group. Retrieved from https://www. universitiesuk.ac.uk/policy-andanalysis/reports/Documents/2011/ report-by-efficiency-and-modernisation-task-group.pdf

33. Webbink, D. (2012). Efficiency in Education. Erasmus School of Economics, University of Rotterdam. Retrieved from https:// www.onderwijsraad.nl/upload/ documents/publicaties/volledig/ Studie-Efficiency-in-education.pdf

34. Wolszczak-Derlacz, J. (2014). An evaluation and explanation of (in)efficiency in higher education institutions in Europe and the U.S. with the application of two-stage semi-parametric DEA (IRLE Working Paper No. 114-14). Institute for Research on Labor and Employment, Berkeley University of California.

35. Worthington, A. C. (2001). An empirical survey of frontier efficiency measurement techniques in education. Education Economics, 9(3), 245-268. http://dx.doi. org/10.1080/09645290110086126

36. Zhang, L., \& Luo, Y. (2016). Evaluation of Input Output Efficiency in Higher Education Based on Data Envelope Analysis. International Journal of Database Theory and Application, 9(5), 221-230. Retrieved from https:// pdfs.semanticscholar.org/3c86/ fa3e53e3e534f31051571e02bfafa650c37b.pdf 